\title{
Vaccination with LytA, LytC, or Pce of Streptococcus pneumoniae Protects against Sepsis by Inducing IgGs That Activate the Complement System
}

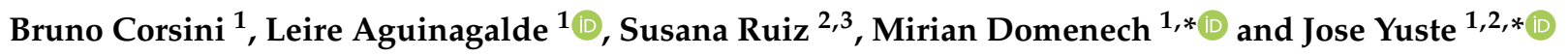 \\ 1 Spanish Pneumococcal Reference Laboratory, National Center for Microbiology, Instituto de Salud Carlos III, \\ 28220 Madrid, Spain; brunoccorsini@gmail.com (B.C.); leire_agui@hotmail.com (L.A.) \\ 2 Centro de Investigación Biomédica en Red de Enfermedades Respiratorias (CIBERES), 28029 Madrid, Spain; \\ sruiz@ciberes.org \\ 3 Centro de Investigaciones Biológicas, Consejo Superior de Investigaciones Científicas, 28040 Madrid, Spain \\ * Correspondence: mdomenech@isciii.es (M.D.); jyuste@isciii.es (J.Y.); Tel.: +34-918223620 (M.D. \& J.Y.)
}

Citation: Corsini, B.; Aguinagalde, L.; Ruiz, S.; Domenech, M.; Yuste, J. Vaccination with LytA, LytC, or Pce of Streptococcus pneumoniae Protects against Sepsis by Inducing IgGs That Activate the Complement System. Vaccines 2021, 9, 186. https:// doi.org/10.3390/vaccines 9020186

Academic Editor: Steven B. Bradfute

Received: 19 January 2021

Accepted: 19 February 2021

Published: 23 February 2021

Publisher's Note: MDPI stays neutral with regard to jurisdictional claims in published maps and institutional affiliations.

Copyright: () 2021 by the authors. Licensee MDPI, Basel, Switzerland. This article is an open access article distributed under the terms and conditions of the Creative Commons Attribution (CC BY) license (https:// creativecommons.org/licenses/by/ $4.0 /)$.

\begin{abstract}
The emergence of non-vaccine serotypes of Streptococcus pneumoniae after the use of vaccines based in capsular polysaccharides demonstrates the need of a broader protection vaccine based in protein antigens and widely conserved. In this study, we characterized three important virulence factors of S. pneumoniae namely LytA, LytC, and Pce as vaccine candidates. These proteins are choline-binding proteins that belong to the cell wall hydrolases' family. Immunization of mice with LytA, LytC, or Pce induced high titers of immunoglobulins G (IgGs) of different subclasses, with IgG1, IgG2a, and IgG2b as the predominant immunoglobulins raised. These antibodies activated the classical pathway of the complement system by increasing the recognition of $\mathrm{C} 1 \mathrm{q}$ on the surface of pneumococcal strains of different serotypes. Consequently, the key complement component C3 recognized more efficiently these strains in the presence of specific antibodies elicited by these proteins, activating, therefore, the phagocytosis. Finally, a mouse sepsis model of infection was established, confirming that vaccination with these proteins controlled bacterial replication in the bloodstream, increasing the survival rate. Overall, these results demonstrate that LytA, LytC, and Pce can be protein antigens to be contained in a future universal vaccine against $S$. pneumoniae.
\end{abstract}

Keywords: S. pneumoniae; vaccine protein; LytA; LytC; Pce; cell wall hydrolases; complement; phagocytosis

\section{Introduction}

Streptococcus pneumoniae is the leading bacterial pathogen of lower respiratory tract infections and a major cause of systemic disease including sepsis and meningitis, which are associated to high morbidity and mortality rates, especially in children under 5 years old and adults aged 65 years and older [1]. Prevention of invasive pneumococcal disease (IPD) is a cost-effective measure and one of the top priorities worldwide to reduce the impact of pneumococcal infections in public health [2-4]. Current prophylactic strategies against $S$. pneumoniae are limited to vaccines based on capsular polysaccharides (CPS). In the pediatric population, the use of pneumococcal conjugate vaccines has significantly reduced the burden of disease caused by serotypes included in these vaccines showing herd effect in adults, confirming the efficacy of these vaccines against vaccine serotypes [5-7]. In adults, the use of the 23-valent pneumococcal polysaccharide vaccine (PPV23) and/or the 13-valent conjugate vaccine (PCV13) in a greater extent have also been effective against IPD and pneumonia caused by serotypes contained in these vaccines [8-12]. However, with up to 100 different serotypes described so far on the basis of CPS, an important limitation of these vaccines is based in the extent number of serotypes of S. pneumoniae [13]. Serotype replacement (emergence of non-vaccine serotypes) is a common scenario for past and 
current anti-pneumococcal vaccines. After the use of the 7-valent pneumococcal conjugate vaccine (PCV7), the emergence of serotype 19A was promptly observed not only in children but also in adults $[7,14]$. This increase was rapidly contained after the introduction of PCV13, compared to countries using the 10-valent pneumococcal conjugate vaccine (PCV10) where this particular serotype remained as an important cause of IPD [12,14-16]. Currently, after a decade of using PCV13, the emergence of non-vaccine serotypes is of great concern worldwide with many countries reporting the rise of non-PCV13 serotypes $[12,14,17,18]$. To solve this problem, the discovery of pneumococcal protein antigens that can confer protection against different serotypes is increasing in the last years and may contribute to a future cocktail of proteins to be incorporated in a future universal vaccine against this important human pathogen [19-26].

One important aspect that should be considered for a vaccine candidate is the potential of the protein target to be an important virulence factor because antibodies elicited against the protein might block and/or attenuate the impact of this protein on pathogenesis $[19,24,27]$. In this sense, the proteins selected for our study play critical roles in different steps of the pathogenesis process. LytA is the main autolysin of the bacterium and is responsible for the release of the citotoxin pneumolysin (Ply) [28,29]. Previous studies by our group using strains lacking Ply, LytA, and both simultaneously demonstrated that LytA is essential in the evasion of the complement-mediated immunity by a Ply-independent mechanism being critical in the direct cleavage of the $\mathrm{C} 3$ component deposited on the bacterial surface [30]. LytC is a lytic enzyme involved in fratricide [31], biofilm formation [32], and adhesion to the nasopharygeal tract [33,34] and avoids the activation of the complement system [34]. Pce (also known as $\mathrm{CbpE}$ ) is a protein involved in the early step process of pathogenesis by participating not only in the attachment to the nasopharynx [33] but also in the release of phosphorylcholine moieties on the bacterial surface, avoiding, therefore, the recognition by acute phase proteins such as C-reactive protein [35].

In this study, we have characterized three different pneumococcal proteins termed LytA, LytC, and Pce as potential vaccine antigens. Mice immunized with these proteins elicited IgG antibodies of different subclasses that increased the activation of C1q and C3 on the surface of pneumococcal strains of different serotypes including multidrug-resistant (MDR) strains leading to enhanced phagocytosis. As a consequence, vaccination with these proteins increased the protection rate against IPD in a mouse sepsis model of infection.

\section{Materials and Methods}

\subsection{Bacterial Strains}

Pneumococcal isolates were cultured on blood agar plates at $37^{\circ} \mathrm{C}$ in $5 \% \mathrm{CO}_{2}$ or in Todd-Hewitt broth supplemented with $0.5 \%$ yeast extract to an optical density at $580 \mathrm{~nm}$ $\left(\mathrm{OD}_{580}\right)$ of 0.4 (approximately $10^{8}$ colony-forming units $(\mathrm{CFU}) / \mathrm{mL}$ ) and stored at $-80{ }^{\circ} \mathrm{C}$ in single-use aliquots containing $10 \%$ glycerol. The specific details (serotype and antibiotic susceptibility) of these strains are described in Table 1.

Table 1. Pneumococcal clinical isolates used in this study. Serotype is indicated as well as the minimum inhibitory concentration (MIC) $(\mu \mathrm{g} / \mathrm{mL})$ to different antibiotics ${ }^{1}$.

\begin{tabular}{cccccccc}
\hline Strain (Serotype) & PEN & AMX & CTX & TET & CHL & ERY & LVX \\
\hline $48(23 \mathrm{~F})$ & 8 & 16 & 8 & 64 & 4 & $>128$ & 2 \\
$69(19 \mathrm{~F})$ & 2 & 2 & 2 & 4 & 4 & $>128$ & 1 \\
$450(11 \mathrm{~A})$ & 2 & 4 & 0.5 & 0.25 & 4 & 0.12 & 1 \\
$957(3)$ & 0.015 & 0.015 & 0.015 & 0.5 & 4 & 0.25 & 1 \\
\hline
\end{tabular}

${ }^{1}$ PEN (penicillin); AMX (amoxicillin); CTX (cefotaxime); TET (tetracycline); CHL (chloramphenicol); ERY (erythromycin); LVX (levofloxacin). 


\subsection{Immunization Experiments in Mice with LytA, LytC, or Pce}

Immunization procedures were performed in groups of $\mathrm{BALB} / \mathrm{c}$ mice that were bred by Instituto de Salud Carlos III (ISCIII) animal facility. All mice used were 8-16 weeks old and, within each experiment, groups of mice were matched for age and sex. Animal experiments were performed at ISCIII in accordance with Spanish legislation (RD 1201/2005, RD 53/2013) and EU regulations (218/63/EU). All animal experiments were approved by the Animal Care and Use Committee of ISCIII (CBA PA 52_2011-v2 and PROEX 218/15). For immunization studies, pneumococcal proteins LytA, LytC, and Pce were purified, as previously described [36-38]. Briefly, pneumococcal proteins were produced from Escherichia coli BL21 (DE3) or E. coli DH5 $\alpha$ containing plasmids pGL100 for LytA, pLCC14 for LytC, and pRGR12 for Pce, as previously described [36-39]. Cells were induced with $100 \mu \mathrm{M}$ of isopropyl-thio- $\beta$-D-galactopyranoside. The incubation proceeded for $16 \mathrm{~h}$ at $25^{\circ} \mathrm{C}$ to minimize the presence of inclusion bodies. Proteins were purified by affinity-chromatography in diethylaminoethyl cellulose equilibrated in $20 \mathrm{mM}$ sodium phosphate. The purity of the isolated samples was routinely analyzed by SDS-PAGE and the proteins were stored at $-20^{\circ} \mathrm{C}$. Protein concentration was determined spectrophotometrically using a Nanodrop ND-1000, measuring at $280 \mathrm{~nm}$. Animals were inoculated with $20 \mu \mathrm{g}$ of each protein mixed in a 1:1 proportion in Alum (Alhydrogel; aluminum hydroxide, InvivoGen) as the adjuvant. Groups of five mice were immunized by intraperitoneal (IP) inoculation of $200 \mu \mathrm{L}$ of Alum alone or $200 \mu \mathrm{L}$ of pneumococcal proteins LytA, LytC, or Pce in Alum adjuvant on days 0, 7 , and 14, as previously described [27,40]. Animals were euthanized on day 21 and blood was collected from cardiac puncture and conserved at $-80^{\circ} \mathrm{C}$ as pooled sera for further in vitro assays. For protection experiments against sepsis, groups of at least 10 mice were immunized as previously described, followed by IP challenge on day 21 with $10^{7} \mathrm{CFU}$ per mouse of serotype $23 \mathrm{~F}$ strain representing at least the lethal dose 50 (LD50) of this strain for systemic infection. Bacterial counts were determined during the first $24 \mathrm{~h}$ from blood samples ( $6 \mu \mathrm{L}$ per mouse) obtained from the tail vein of infected animals, as previously described $[27,41]$. Pneumococcal disease was monitored daily until seven days, and mice were sacrificed when they exhibited severe signs of disease.

\subsection{Enzyme-Linked Immunosorbent Assays to Detect Ig Subclasses}

Specific antibody titers present in pooled sera from five mice of each group were measured by enzyme-linked immunosorbent assays (ELISA). We used 96-well polystyrene Maxisorp plates (Nunc) coated with $0.5 \mu \mathrm{g}$ of purified LytA, LytC, or Pce protein for $2 \mathrm{~h}$ at $37^{\circ} \mathrm{C}$ and blocked with a phosphate buffer saline- $2 \%$ bovine serum albumin (PBS- $2 \%$ BSA) solution, as previously described [27]. Bound antibodies were detected by using horseradish peroxidase (HRP)-conjugated goat anti-mouse IgG, IgG1, IgG2a, IgG2b, and IgG3 (Santa Cruz) for $30 \mathrm{~min}$ and developed using o-phenylenediamine (Sigma-Aldrich) before determining the $\mathrm{OD}_{492}$ using a microtiter plate reader (Anthos 2020).

\subsection{Activation of Complement-Mediated Immunity by Specific IgGs}

Complement activation was determined by measuring $\mathrm{C} 1 \mathrm{q}$ and $\mathrm{C} 3$ using flow cytometry assays, as described before [30,42-44]. Briefly, C1q binding was analyzed by incubating $5 \times 10^{6} \mathrm{CFU}$ of $S$. pneumoniae in $10 \mu \mathrm{L}$ of serum (diluted to $50 \%$ in PBS) for $30 \mathrm{~min}$ at $37^{\circ} \mathrm{C}$ using pooled sera from mice immunized with Alum alone or immunized with LytA-Alum, LytC-Alum, or Pce-Alum. Bacteria were then incubated for $1 \mathrm{~h}$ with rabbit anti-mouse C1q antibody (Abcam) followed by an additional incubation with fluorescein isothiocyanate (FITC)-conjugated polyclonal goat anti-rabbit IgG. Then, bacteria were fixed in 3\% paraformaldehyde (PFA) and analyzed on a FACS Calibur flow cytometer (BD Biosciences) using forward and side scatter parameters to gate on at least 25,000 cells. This protocol was adapted for $\mathrm{C} 3$ deposition. After the 30 -min opsonization at $37^{\circ} \mathrm{C}$ with mice sera (as described above), bacteria were incubated for $30 \mathrm{~min}$ on ice with FITC-conjugated polyclonal goat antimouse C3 antibody (ICN-Cappel) diluted 1/300 in PBS. Fixation with PFA and analysis by flow cytometry were similar to those performed for $\mathrm{C} 1 \mathrm{q}$ assays. 
The results were expressed as a relative percent fluorescence index (\% RFI) that measures not only the proportion of fluorescent bacteria positive for the host serum component investigated but also the intensity of fluorescence that quantifies the immune component bound $[27,44,45]$.

\subsection{Opsonophagocytosis (OP) Using HL-60 Cells}

Phagocytosis assays were assessed using a flow cytometry assay including S. pneumoniae strains, described above. These strains were fluorescently labeled with 5,6- carboxyfluorescein succinimidyl ester (FAM-SE; Molecular Probes) and exposed to human HL-60 cells (CCL-240; ATCC) differentiated to granulocytes. The general conditions of the assay were based on those described previously except that clinical isolates were incubated with pooled sera from mice immunized with Alum alone or immunized with the mixture LytA-Alum, LytC-Alum, or Pce-Alum [27,46,47]. The multiplicity of infection of OP assays followed a ratio of 10 bacteria per cell. A minimum of 6000 cells was analyzed using a FACS Calibur flow cytometer. Results were expressed as a RFI, defined as the proportion of positive cells for fluorescent bacteria multiplied by the geometric mean of fluorescence intensity, which correlates with the amount of bacteria phagocytosed per cell.

\subsection{Statistical Analysis}

Data are representative of results obtained from at least three independent experiments, and each data point represents the mean and standard deviations (SD) for 3-5 replicates. Statistical analysis was performed by using two-tailed Student's $t$-test (for two groups), whereas analysis of variance (ANOVA) followed by a Dunnett's post hoc test was chosen for multiple comparisons. Survival was analyzed by the log-rank test. GraphPad InStat version 6.0 (GraphPad Software, San Diego, CA) was used for statistical analysis. Differences were considered statistically significant with $p<0.05\left(^{*}\right)$ and highly significant with $p<0.01\left(^{* *}\right)$ and $\left.p<0.001{ }^{* * *}\right)$.

\section{Results}

\subsection{Antibody Response to Cell Wall Hydrolases LytA, LytC, and Pce}

The immunological responses measured as IgGs of different subclasses after vaccination of mice with LytA, LytC, or Pce were assessed using ELISA specific for murine sera including total IgG, IgG1, IgG2a, IgG2b, and IgG3. Antibody levels were investigated in normal mouse serum (NMS) from naïve (non-immunized) mice or sera from mice immunized with Alum alone or with mixed LytA-Alum, LytC-Alum, or Pce-Alum. Sera from mice immunized with each of the proteins investigated elicited strong IgG levels compared to Alum alone and NMS (Figure 1A). Immunization with LytA, LytC, or Pce induced consistent levels of IgGs, predominantly of subclasses IgG1 and IgG2b followed by IgG2a and IgG3 (Figure 1). Overall, these results suggest that pneumococcal LytA, LytC, and Pce are immunogenic proteins that elicit systemic IgG antibodies of different subclasses that might be protective for IPD in terms of further activation of the host-immune response. 

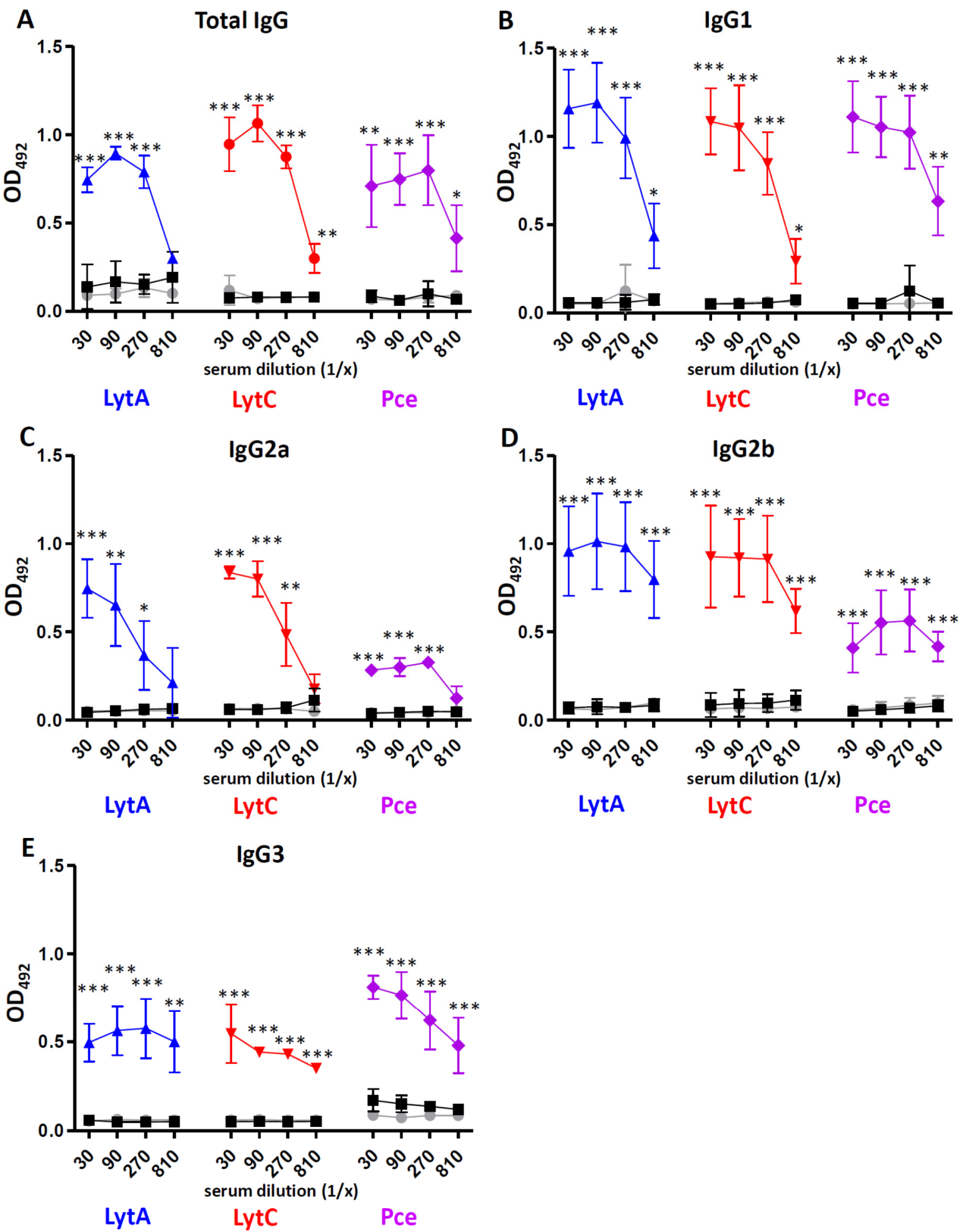

Figure 1. Antibody levels in sera after immunization of mice with Alum or different cell wall hydrolases (LytA, LytC, or Pce) mixed in Alum including total IgG (A), IgG1 (B), IgG2a (C), IgG2b (D), and IgG3 (E). Specific antibodies were measured in NMS (gray circles), pooled sera from mice immunized with Alum as adjuvant (black squares) and pooled sera from mice immunized with $20 \mu \mathrm{g}$ of LytA-Alum (blue triangles), LytC-Alum (red circles), or Pce-Alum (purple diamonds). Error bars represent the SDs and asterisks indicate statistical significance of immunization of each protein compared to the Alum group; ${ }^{*} p<0.05 ;{ }^{* *} p<0.01 ;{ }^{* *} p<0.001$. 


\subsection{Complement Activation Mediated by Antibodies to LytA, LytC, or Pce}

Recognition by C1q, the first component of the classical pathway, was investigated analyzing four different clinical isolates of S. pneumoniae (Figure 2). For these assays, we used pooled sera from mice immunized with Alum alone or with LytA-Alum, LytC-Alum, or Pce-Alum (Figure 2). Incubation of pneumococcal clinical isolates with sera containing specific antibodies to LytA, LytC, or Pce increased the recognition by $\mathrm{C} 1 \mathrm{q}$, indicating that immunization with these proteins triggers activation of the classical pathway against $S$. pneumoniae and that this effect seems to be serotype independent (Figure 2).
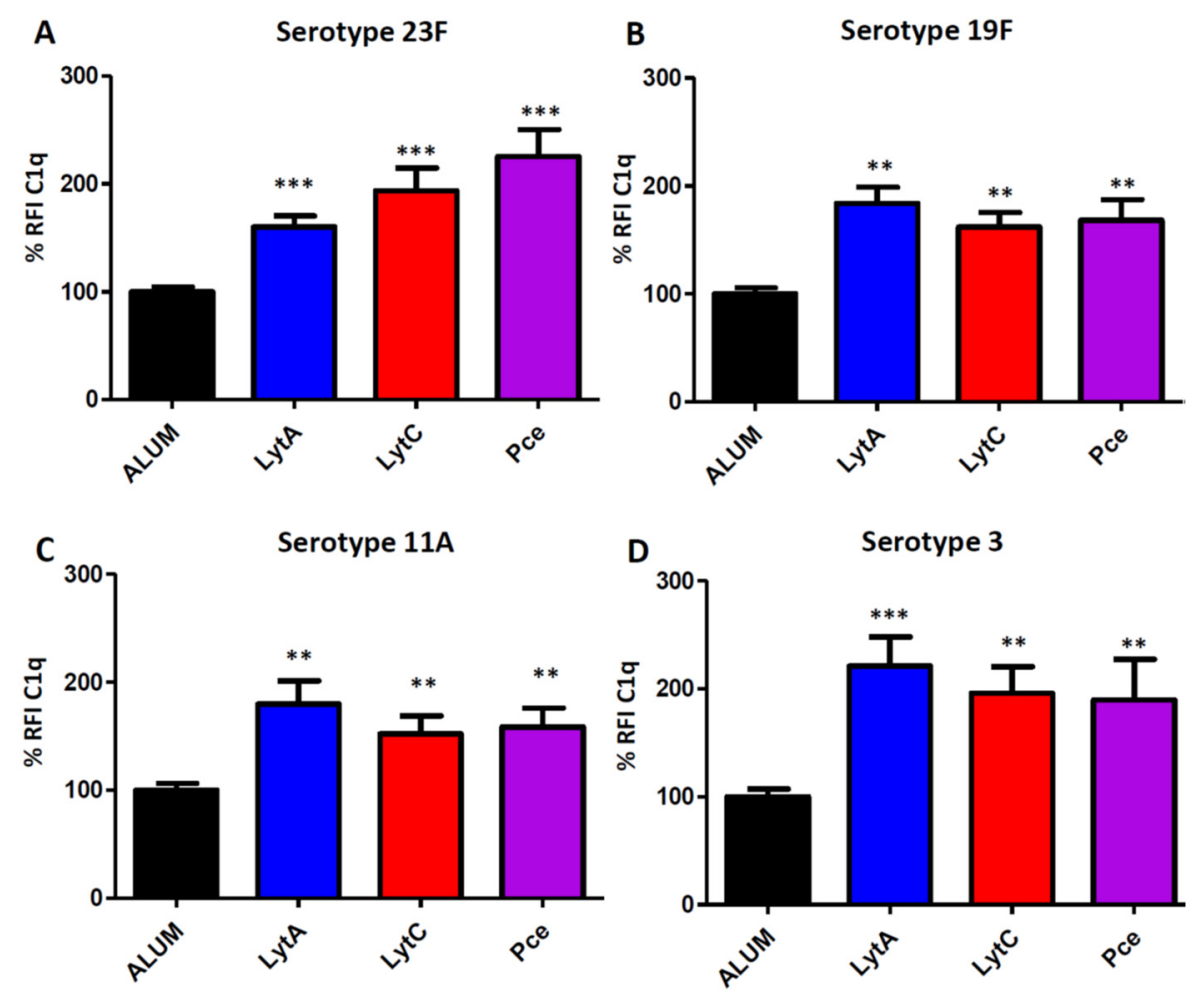

E

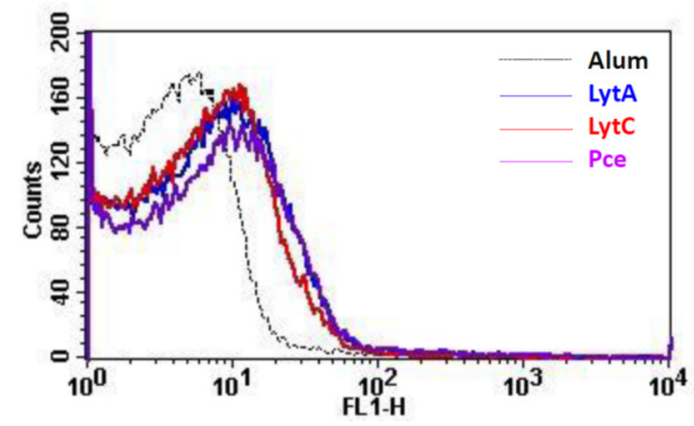

Figure 2. Classical pathway activation mediated by antibodies against LytA, LytC, or Pce. These assays measured deposition of mouse $\mathrm{C} 1 \mathrm{q}$ on the surface of the corresponding bacterial strain using pooled sera from mice immunized with Alum (black bars) or with LytA-Alum (blue bars), LytC-Alum (red bars), or Pce-Alum (purple bars). (A) Strain 48 (serotype 23F). (B) Strain 69 (serotype 19F). (C) Strain 450 (serotype 11A). (D) Strain 957 (serotype 3). (E) Example of a flow cytometry histogram for $\mathrm{C} 1 \mathrm{q}$ deposition on the serotype $23 \mathrm{~F}$ strain. Results are expressed as a relative \% fluorescence index (\% RFI). Error bars represent the SDs and asterisks indicate statistical significance of LytA, LytC, or Pce immunization compared to the Alum group; ${ }^{* *} p<0.01 ;{ }^{* * *} p<0.001$.

In addition, recognition by the key complement opsonin C3 was explored for the different clinical isolates (Figure 3). Hence, C3 deposition on the pneumococcal surface 
was significantly enhanced in the presence of specific antibodies to each of the proteins investigated (LytA, LytC, or Pce) (Figure 3).
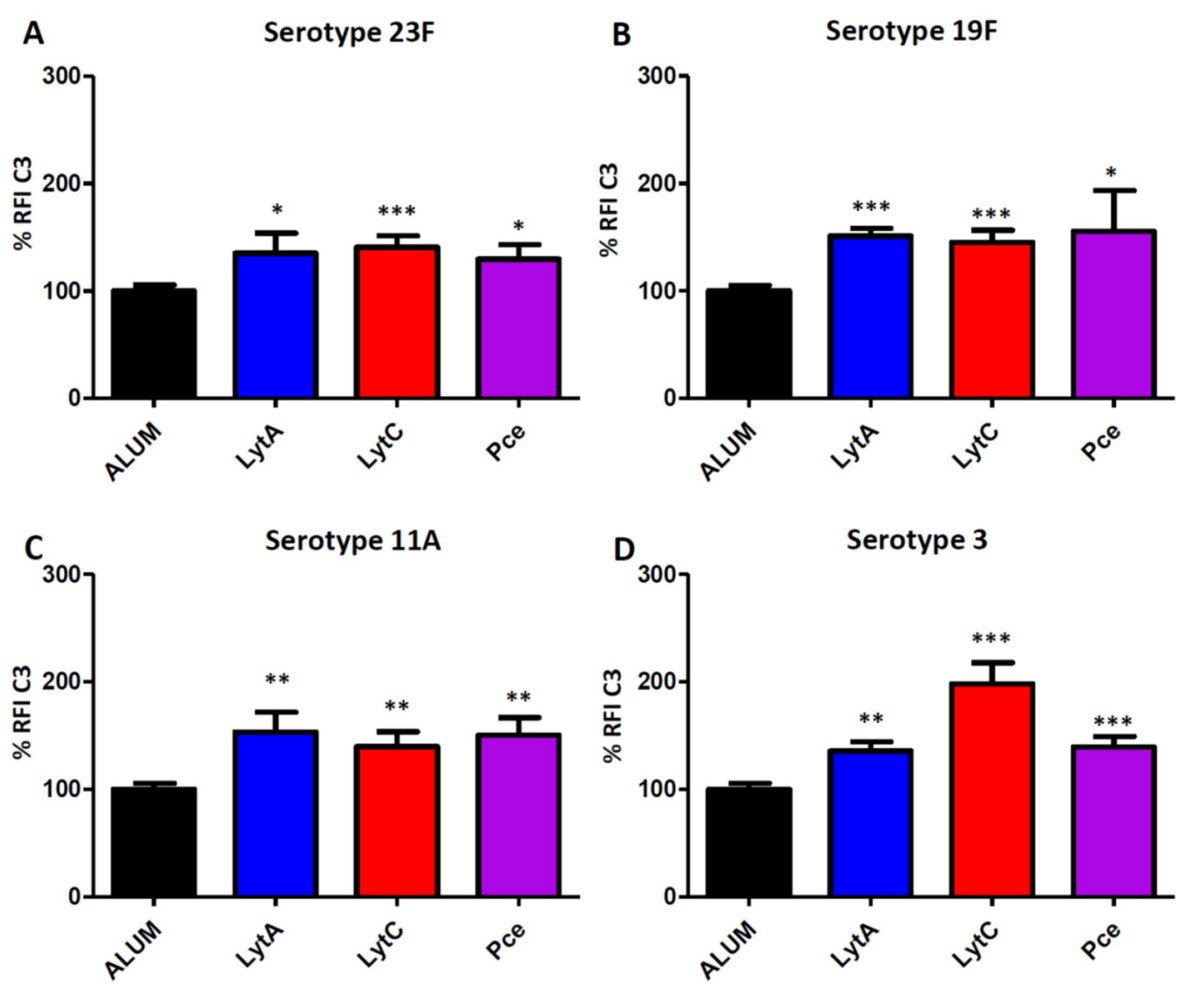

E

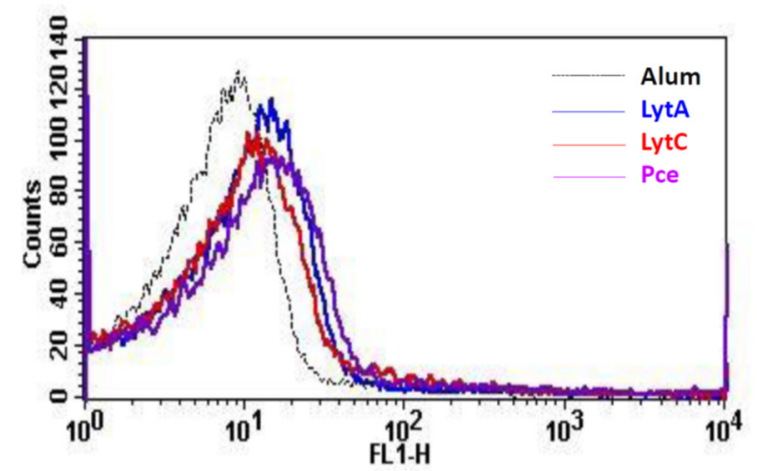

Figure 3. Recognition of different pneumococcal serotypes by C3 mediated by antibodies to LytA, $\mathrm{LytC}$, or Pce. The different strains were exposed to pooled sera from mice immunized with Alum (black bar) or with LytA-Alum (blue bars), LytC-Alum (red bars), or Pce-Alum (purple bars). (A) Strain 48 (serotype 23F). (B) Strain 69 (serotype 19F). (C) Strain 450 (serotype 11A). (D) Strain 957 (serotype 3). (E) Example of a flow cytometry histogram for C1q deposition on the serotype 23F strain. Results are expressed as \% RFI. Error bars represent the SDs and asterisks indicate statistical significance of LytA, LytC, or Pce immunization compared to the Alum group; ${ }^{*} p<0.05$; ${ }^{* *} p<0.01$; $* * * p<0.001$.

Overall, these results investigating the interaction of complement components in the presence of antibodies to $\mathrm{LytA}, \mathrm{LytC}$, or PCe demonstrated that vaccination with these proteins induces complement-mediated responses against different serotypes of $S$. pneumoniae (Figures 2 and 3). 
3.3. Immunization with LytA, LytC, or Pce Induces Activation of the Opsonophagocytosis Process of S. pneumoniae Regardless of the Serotype

For OP assays, FAM-SE-labeled S. pneumoniae strains of the four different serotypes of this study were incubated with sera from mice immunized only with Alum or with LytA, LytC, or Pce proteins mixed with Alum. As negative control, bacteria incubated with Hank's balanced salt solution (HBSS) were included to evaluate the phagocytosis level in the absence of serum components. In the HBSS control, phagocytosis was significantly reduced in comparison to the Alum group and markedly impaired compared to LytA, LytC, or Pce immune sera, confirming, therefore, the importance of complement components in phagocytosis mediated by antibodies to these proteins (Figure 4). The level of phagocytosis was significantly higher in the presence of antibodies to LytA, LytC, or Pce in comparison to Alum group, demonstrating that immunization with those cell wall hydrolases LytA, LytC, or Pce stimulates phagocytosis of S. pneumoniae regardless of the serotype.
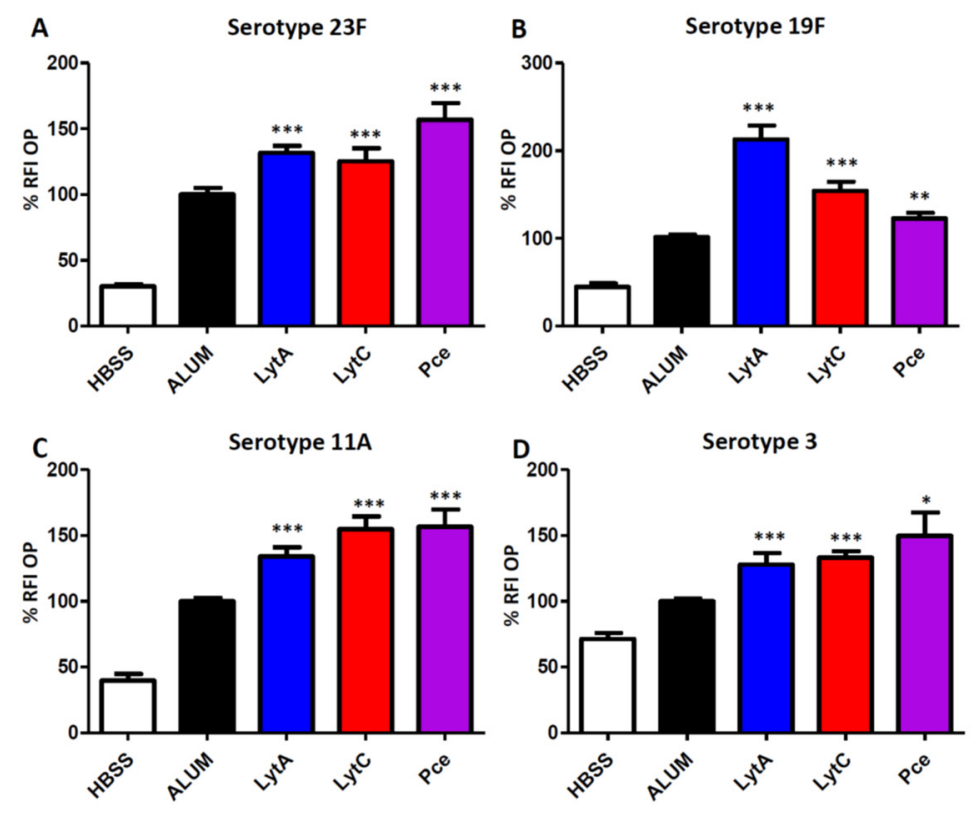

E

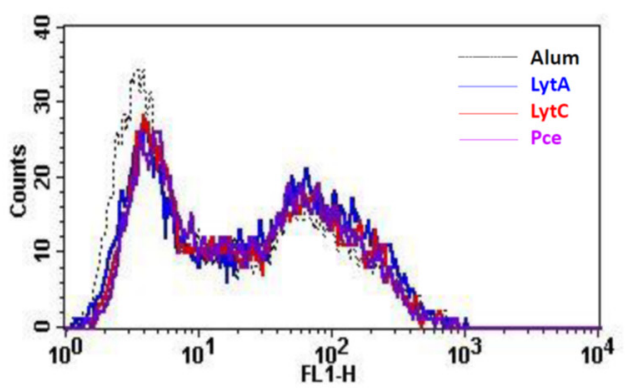

Figure 4. OP assays using the HL-60 neutrophil cell line and S. pneumoniae strains incubated with HBSS (white bar) or pooled sera from mice immunized with Alum (black bar) or with LytA-Alum (blue bars), LytC-Alum (red bars), or Pce-Alum (purple bars). (A) Strain 48 (serotype 23F). (B) Strain 69 (serotype 19F). (C) Strain 450 (serotype 11A). (D) Strain 957 (serotype 3). (E) Example of a flow cytometry histogram for OP of the clinical isolate of serotype 23F. Results are expressed as \% RFI. Error bars represent the SDs and asterisks indicate statistical significance of LytA, LytC, or Pce immunization compared to the Alum group; ${ }^{*} p<0.05 ;{ }^{* *} p<0.01$; ${ }^{* *} p<0.001$. 


\subsection{Vaccination with LytA, LytC, or Pce Protects Mice against Systemic Infection by S. Pneumoniae}

IPD is a devastating infectious process that, when produced by strains showing high levels of antibiotic resistance, is associated to high mortality rates. The individual protective activity of LytA, LytC, or Pce against IPD was investigated in a sepsis model of infection caused by the strain 48 (serotype 23F), which is an MDR clinical isolate of S. pneumoniae (Figure 5). Groups of mice were immunized with $20 \mu \mathrm{g}$ of either LytA, LytC, or Pce and survival and bacterial levels in blood were analyzed. Vaccination with each of these proteins decreased bacterial counts in blood at $24 \mathrm{~h}$ in comparison to Alum group and increased survival rates against sepsis caused by the MDR strain (Figure 5). The surviving mice at day $7 \mathrm{did}$ not have bacterial counts in blood, confirming that vaccination with these proteins cleared the systemic infection. These results confirmed that these proteins might be promising vaccine candidates against pneumococcal sepsis caused by antibiotic-resistant strains.
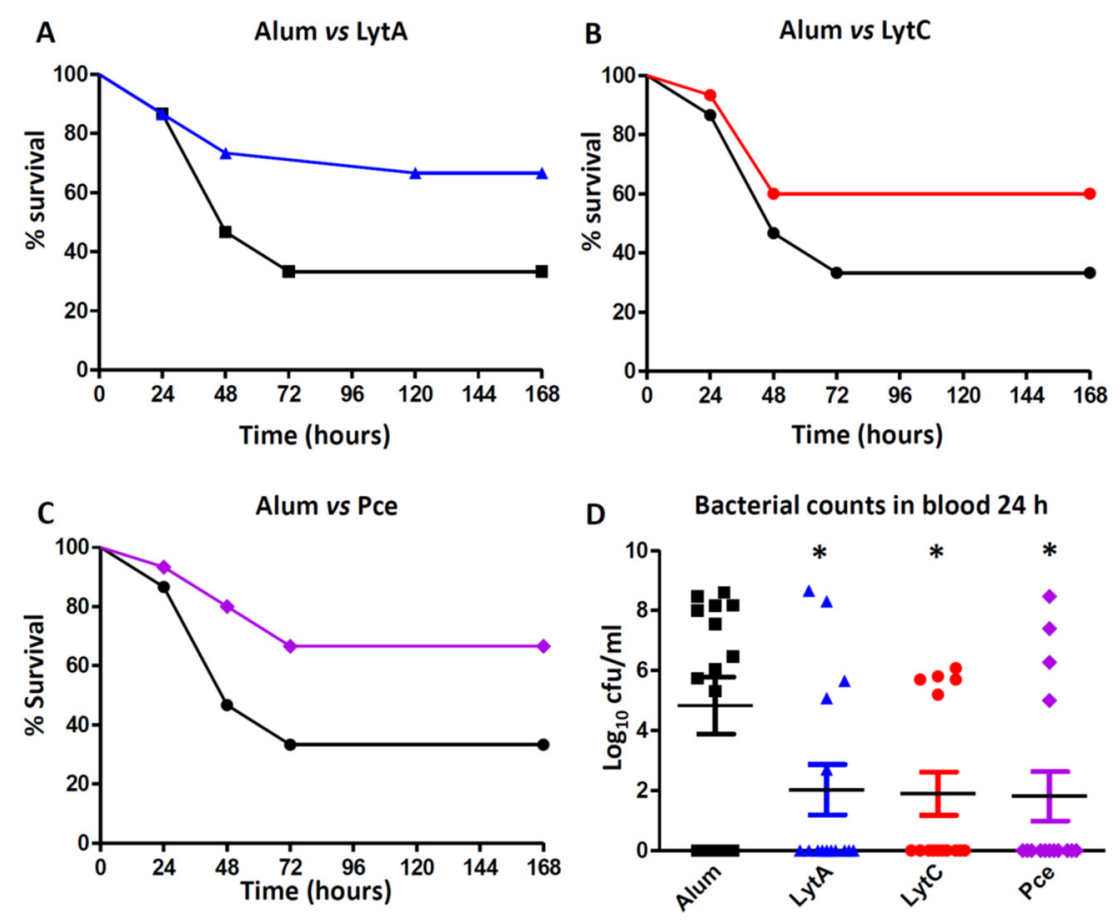

Figure 5. Protection mediated by LytA, LytC, or Pce against pneumococcal sepsis caused by strain 48 (serotype 23F). Mice were vaccinated with Alum or with $20 \mu \mathrm{g}$ of the specific protein (LytA, LytC, or Pce) mixed with Alum. (A) Survival in mice vaccinated with Alum (black line) or LytA-Alum (blue line). (B) Survival in mice vaccinated with Alum (black line) or LytC-Alum (red line). (C) Survival in mice vaccinated with Alum (black line) or Pce-Alum (purple line). (D) Bacterial counts in blood at $24 \mathrm{~h}$ from mice immunized with Alum or proteins (LytA, LytC, or Pce) mixed with Alum. Error bars represent the SDs and asterisks indicate statistical significance of vaccination with LytA, LytC, or Pce compared to the Alum group; ${ }^{*} p<0.05$.

\section{Discussion}

Characterization of pneumococcal proteins as vaccine antigens is necessary in the existing epidemiological context of IPD because they can offer cheaper and affordable alternatives of broad coverage without promoting the serotype replacement phenomena that is frequently observed after implementation of current prophylactic measures based in CPS vaccines $[12,14,17]$. In this study, we characterized three pneumococcal proteins such as LytA, LytC, and Pce that belong to the choline-binding protein family and are classified as cell wall hydrolases because they are endogenous enzymes that specifically cleave covalent bonds of the cell wall [48]. These proteins are highly conserved and are involved in fundamental biological functions such as the synthesis of the bacterial cell wall, 
cell shape preservation, or daughter cell separation, playing a critical role in the irreversible effects caused by certain antibiotics such as $\beta$-lactam antibiotics [48]. In the case of LytA, although two families of LytA alleles have been described, nucleotide polymorphism does not affect the primary structure of the protein, in which perfect amino acid sequence conservation was observed [49]. LytC and Pce (CbpE) are also good examples of common proteins found in the pneumococcal diverse population. The pneumococcal gene $\mathrm{LytC}$ was detected in $100 \%$ of nasopharyngeal samples and was the gene with the highest level of expression $\left(>10^{4}\right.$ copies $\left./ \mathrm{mL}\right)$ of the human nasopharynx [50], whereas Pce was found in all the clinical isolates investigated regardless of the serotype [51].

LytA, LytC, and Pce are surface-exposed proteins, which is an important feature for a vaccine protein candidate due to their physical accessibility to be recognized by opsonizing antibodies and because they can interact with important components of the immune system involved in the generation of specific and long-term production of immune responses [20]. One important aspect that increases the interest for an antigen to become a vaccine candidate is the relevance of the protein in the virulence of the microorganism. These three proteins play key roles in different phases of the pathogenesis process, although one common feature among these three proteins is that they avoid the complement-mediated immunity and phagocytosis leading to the development of pneumonia and IPD [30,34,35].

In this study, we used alhydrogel as adjuvant in the immunization of mice because this adjuvant has been approved for human use in studies evaluating pneumococcal proteins [52,53]. Vaccination with LytA, LytC, or Pce was able to induce strong IgG responses of different subclasses such as IgG1, IgG2a, and IgG2b as predominant and IgG3 in a lesser degree. This aspect is relevant from the immunogenic perspective because the current PPV23 vaccine also elicits some of these subtypes of IgGs, predominantly of the IgG2 subclass [54,55]. Moreover, these three proteins also produced antibodies similar to those elicited by PCVs. In adults, PCVs produce predominantly an IgG2 response, whereas in children the primary response is of the IgG1 subtype [55-57]. Overall, the wide variety of IgG antibodies observed after vaccination with LytA, LytC, or Pce suggests that these proteins could be potential antigens for a vaccine targeting the pediatric and elderly population who are the major age groups at risk for developing IPD. Production of a robust IgG response has functional consequences because IgG1 and IgG3 antibodies induce a higher level of recognition by complement components and stronger interaction with Fc $\gamma$ receptors than IgG2 [58-60]. Hence, incubation of pneumococcal strains of four different serotypes with antibodies to LytA, LytC, or Pce increased the recognition by $\mathrm{C} 1 \mathrm{q}$, demonstrating that vaccination with these proteins triggers the activation of the classical pathway. This is of great relevance from the pneumococcal pathogenesis perspective as this pathway plays a critical role in host defense against S. pneumoniae in human and mice [42,61]. In addition, vaccination with any of these three proteins activated the opsonization of different pneumococcal strains by the key complement protein C3, which is an essential component for further activation of the phagocytosis process [42]. In this sense, we found that antibodies to LytA, LytC, or Pce increased OP by human neutrophils and this effect was independent of the CPS as antibodies elicited by any of these three proteins efficiently recognized different serotypes. This is in agreement with current commercialized pneumococcal vaccines, as opsonophagocytosis is a widely accepted method to demonstrate that antibodies elicited by these vaccines are functional $[62,63]$. Our results are interesting in terms of functional protection because the efficacy of the host immune system to recognize and destroy S. pneumoniae depends on OP by neutrophils as one of the most relevant phagocytes against this bacterium $[47,64]$, as it can be seen in neutropenic patients who are highly susceptible to pneumococcal infection [65]. Our findings are in agreement with previous observations using LytB, which is a different cell wall hydrolase, as vaccination with this protein also activated complement-mediated phagocytosis [27].

Immunization with LytA, LytC, or Pce produced an IgG3 response that may be important against invasive disease as this immunoglobulin is highly protective against systemic 
pneumococcal infection [66]. Our results demonstrated that mice vaccinated with these proteins controlled bacterial replication in the systemic circulation, reducing the severity of the infection process and leading to increasing survival rates. These results for LytA and $\mathrm{LytC}$ as potential vaccine antigens are in agreement with previous reports showing that immunization of mice with LytA or LytC increased the survival in comparison to the placebo group, although the immunological mechanism responsible for this protective effect was not explored $[28,67,68]$. In addition, the immunogenicity of these two proteins was confirmed using human sera from convalescent patients suffering IPD, demonstrating the presence of IgG antibodies against LytA and LytC in these patients [20,67]. In the case of Pce, our study is the first report showing not only that this protein is immunogenic but also induces activation of the host-immune response by a complement-dependent mechanism and vaccination with this protein confers protection against sepsis.

We used an MDR clinical isolate displaying high levels of antibiotic resistance to $\beta$-lactam antibiotics and macrolides to evaluate the protective capacity of the cell wall hydrolases. The reason for using this strain was because, in the clinical practice and from an epidemiology perspective, these strains are of great concern worldwide and a serious threat for the outcome of the infection and, therefore, prevention of IPD caused by these strains is a priority [69-71]. The main limitation of MDR strains is that acquisition of antibiotic resistance is associated to a certain loss of virulence in mice models of infection and that may be the reason that we did not observe full lethality in the placebo group immunized with alum as adjuvant [72,73]. Overall, the results of our study suggest that LytA, LytC, and Pce are promising antigen candidates to be considered in a future universal vaccine against systemic infection caused by S. pneumoniae.

The use of proteins as vaccine candidates can offer certain advantages compared to traditional vaccines based in capsular polysaccharides such as broader coverage and cheaper production. However, vaccine antigens based in bacterial proteins, such as the serogroup $B$ meningococcal vaccine, do not provide a clear impact on carriage in vaccinated children $[74,75]$. Cocktails of pneumococcal proteins or even combination of vaccine proteins with pneumococcal polysaccharides can provide additive or synergistic effects that may be beneficial and reduce the impact of allelic variation [19,21-25]. In this sense, additional studies combining cell wall hydrolases including LytB might be a promising alternative that deserves further research

\section{Conclusions}

This study demonstrated that immunization with cell wall hydrolases LytA, LytC, or Pce of S. pneumoniae elicited an antibody response of IgGs of different subclasses including IgG1, IgG2a, IgG2b, and IgG3. These antibodies increased complement-mediated phagocytosis through activation of the classical pathway. Vaccination with these proteins controlled bacterial replication in the bloodstream, increasing the survival against systemic infection caused by an MDR pneumococcal strain.

Author Contributions: Conceptualization, B.C., M.D., and J.Y.; methodology, B.C., L.A., and S.R.; formal analysis, B.C., M.D., and J.Y.; investigation, B.C., L.A., S.R., and J.Y.; writing-original draft preparation, M.D. and J.Y.; writing-review and editing, M.D., and J.Y. All authors have read and agreed to the published version of the manuscript.

Funding: This research was funded by Ministerio de Economía, Industria y Competitividad (grant number SAF2017-83388). B.C. and L.A. were supported, respectively, by a fellowship from the Brazilian Program Ciencia Sem Fronteiras (CsF) from Conselho Nacional de Desenvolvimento Científico e Tecnológico (CNPq) and by an FPI fellowship from MINECO.

Institutional Review Board Statement: The study was approved by Ethics Committee of the Animal Care and Use Committee of ISCIII (CBA PA 52_2011-v2 and PROEX 218/15, August 2015) in accordance with Spanish legislation (RD 1201/2005, RD 53/2013) and EU regulations (218/63/EU).

Informed Consent Statement: Not applicable. 
Data Availability Statement: The data presented in this study is contained within the article.

Acknowledgments: We thank Dolores Vicioso, Isabel Hernández, and Asunción Fenoll for technical help. The critical reading of the manuscript by Ernesto García is greatly acknowledged.

Conflicts of Interest: The authors declare no conflict of interest related to this work.

\section{References}

1. GBD 2016 Lower Respiratory Infections Collaborators. Estimates of the global, regional, and national morbidity, mortality, and aetiologies of lower respiratory infections in 195 countries, 1990-2016: A systematic analysis for the Global Burden of Disease Study 2016. Lancet Infect. Dis. 2018, 18, 1191-1210. [CrossRef]

2. Kyaw, M.H.; Lynfield, R.; Schaffner, W.; Craig, A.S.; Hadler, J.; Reingold, A.; Thomas, A.R.; Harrison, L.H.; Bennett, N.M.; Farley, M.M.; et al. Effect of introduction of the pneumococcal conjugate vaccine on drug-resistant Streptococcus pneumoniae. N. Engl. J. Med. 2006, 354, 1455-1463. [CrossRef] [PubMed]

3. McLaughlin, J.M.; Jiang, Q.; Isturiz, R.E.; Sings, H.L.; Swerdlow, D.L.; Gessner, B.D.; Carrico, R.M.; Peyrani, P.; Wiemken, T.L.; Mattingly, W.A.; et al. Effectiveness of 13-Valent Pneumococcal Conjugate Vaccine Against Hospitalization for CommunityAcquired Pneumonia in Older US Adults: A Test-Negative Design. Clin. Infect. Dis. 2018, 67, 1498-1506. [CrossRef] [PubMed]

4. Whitney, C.G.; Farley, M.M.; Hadler, J.; Harrison, L.H.; Bennett, N.M.; Lynfield, R.; Reingold, A.; Cieslak, P.R.; Pilishvili, T.; Jackson, D.; et al. Decline in invasive pneumococcal disease after the introduction of protein-polysaccharide conjugate vaccine. $N$. Engl. J. Med. 2003, 348, 1737-1746. [CrossRef] [PubMed]

5. Regev-Yochay, G.; Katzir, M.; Strahilevitz, J.; Rahav, G.; Finn, T.; Miron, D.; Maor, Y.; Chazan, B.; Schindler, Y.; Dagan, R.; et al. The herd effects of infant PCV7/PCV13 sequential implementation on adult invasive pneumococcal disease, six years post implementation; a nationwide study in Israel. Vaccine 2017, 35, 2449-2456. [CrossRef] [PubMed]

6. Jayasinghe, S.; Menzies, R.; Chiu, C.; Toms, C.; Blyth, C.C.; Krause, V.; McIntyre, P. Long-term impact of a "3 + 0" schedule for 7and 13-valent pneumococcal conjugate vaccines on invasive pneumococcal disease in Australia, 2002-2014. Clin. Infect. Dis. 2017, 64, 175-183. [CrossRef]

7. Fenoll, A.; Granizo, J.J.; Gimenez, M.J.; Yuste, J.; Aguilar, L. Secular trends (1990-2013) in serotypes and associated nonsusceptibility of S. pneumoniae isolates causing invasive disease in the pre-/post-era of pneumococcal conjugate vaccines in Spanish regions without universal paediatric pneumococcal vaccination. Vaccine 2015, 33, 5691-5699. [CrossRef] [PubMed]

8. Falkenhorst, G.; Remschmidt, C.; Harder, T.; Hummers-Pradier, E.; Wichmann, O.; Bogdan, C. Effectiveness of the 23-valent pneumococcal polysaccharide vaccine (PPV23) against pneumococcal disease in the elderly: Systematic review and meta-analysis. PLoS ONE 2017, 12, e0169368. [CrossRef]

9. Lawrence, H.; Pick, H.; Baskaran, V.; Daniel, P.; Rodrigo, C.; Ashton, D.; Edwards-Pritchard, R.C.; Sheppard, C.; Eletu, S.D.; Litt, D.; et al. Effectiveness of the 23-valent pneumococcal polysaccharide vaccine against vaccine serotype pneumococcal pneumonia in adults: A case-control test-negative design study. PLoS Med. 2020, 17, e1003326. [CrossRef] [PubMed]

10. Bonten, M.J.; Huijts, S.M.; Bolkenbaas, M.; Webber, C.; Patterson, S.; Gault, S.; van Werkhoven, C.H.; van Deursen, A.M.; Sanders, E.A.; Verheij, T.J.; et al. Polysaccharide conjugate vaccine against pneumococcal pneumonia in adults. N. Engl. J. Med. 2015, 372, 1114-1125. [CrossRef] [PubMed]

11. McLaughlin, J.M.; Jiang, Q.; Gessner, B.D.; Swerdlow, D.L.; Sings, H.L.; Isturiz, R.E.; Jodar, L. Pneumococcal conjugate vaccine against serotype 3 pneumococcal pneumonia in adults: A systematic review and pooled analysis. Vaccine 2019, 37, 6310-6316. [CrossRef]

12. de Miguel, S.; Domenech, M.; González-Camacho, F.; Sempere, J.; Vicioso, D.; Sanz, J.C.; García Comas, L.; Ardanuy, C.; Fenoll, A.; Yuste, J. Nationwide trends of invasive pneumococcal disease in Spain (2009-2019) in children and adults during the pneumococcal conjugate vaccine era. Clin. Infect. Dis. 2020. [CrossRef]

13. Ganaie, F.; Saad, J.S.; McGee, L.; van Tonder, A.J.; Bentley, S.D.; Lo, S.W.; Gladstone, R.A.; Turner, P.; Keenan, J.D.; Breiman, R.F.; et al. A New Pneumococcal capsule type, 10D, is the 100th serotype and has a large cps fragment from an oral Streptococcus. mBio 2020, 11. [CrossRef] [PubMed]

14. Ladhani, S.N.; Collins, S.; Djennad, A.; Sheppard, C.L.; Borrow, R.; Fry, N.K.; Andrews, N.J.; Miller, E.; Ramsay, M.E. Rapid increase in non-vaccine serotypes causing invasive pneumococcal disease in England and Wales, 2000-2017: A prospective national observational cohort study. Lancet Infect. Dis. 2018, 18, 441-451. [CrossRef]

15. Cassiolato, A.P.; Almeida, S.C.G.; Andrade, A.L.; Minamisava, R.; Brandileone, M.C.C. Expansion of the multidrug-resistant clonal complex 320 among invasive Streptococcus pneumoniae serotype 19A after the introduction of a ten-valent pneumococcal conjugate vaccine in Brazil. PLoS ONE 2018, 13, e0208211. [CrossRef]

16. Savulescu, C.; Krizova, P.; Lepoutre, A.; Mereckiene, J.; Vestrheim, D.F.; Ciruela, P.; Ordobas, M.; Guevara, M.; McDonald, E.; Morfeldt, E.; et al. Effect of high-valency pneumococcal conjugate vaccines on invasive pneumococcal disease in children in SpIDnet countries: An observational multicentre study. Lancet Respir. Med. 2017, 5, 648-656. [CrossRef]

17. Ouldali, N.; Varon, E.; Levy, C.; Angoulvant, F.; Georges, S.; Ploy, M.C.; Kempf, M.; Cremniter, J.; Cohen, R.; Bruhl, D.L.; et al. Invasive pneumococcal disease incidence in children and adults in France during the pneumococcal conjugate vaccine era: An interrupted time-series analysis of data from a 17-year national prospective surveillance study. Lancet Infect. Dis. 2020. [CrossRef] 
18. Sempere, J.; de Miguel, S.; González-Camacho, F.; Yuste, J.; Domenech, M. Clinical relevance and molecular pathogenesis of the emerging serotypes $22 \mathrm{~F}$ and $33 \mathrm{~F}$ of Streptococcus pneumoniae in Spain. Front. Microbiol. 2020, 11. [CrossRef]

19. Feldman, C.; Anderson, R. Review: Current and new generation pneumococcal vaccines. J. Infect. 2014, 69, 309-325. [CrossRef]

20. Giefing, C.; Meinke, A.L.; Hanner, M.; Henics, T.; Bui, M.D.; Gelbmann, D.; Lundberg, U.; Senn, B.M.; Schunn, M.; Habel, A.; et al. Discovery of a novel class of highly conserved vaccine antigens using genomic scale antigenic fingerprinting of pneumococcus with human antibodies. J. Exp. Med. 2008, 205, 117-131. [CrossRef]

21. Chan, W.Y.; Entwisle, C.; Ercoli, G.; Ramos-Sevillano, E.; McIlgorm, A.; Cecchini, P.; Bailey, C.; Lam, O.; Whiting, G.; Green, N.; et al. A Novel, Multiple-Antigen Pneumococcal Vaccine Protects against Lethal Streptococcus pneumoniae Challenge. Infect. Immun. 2019, 87. [CrossRef]

22. Converso, T.R.; Goulart, C.; Darrieux, M.; Leite, L.C.C. A protein chimera including PspA in fusion with PotD is protective against invasive pneumococcal infection and reduces nasopharyngeal colonization in mice. Vaccine 2017, 35, 5140-5147. [CrossRef] [PubMed]

23. Brown, J.S.; Ogunniyi, A.D.; Woodrow, M.C.; Holden, D.W.; Paton, J.C. Immunization with components of two iron uptake ABC transporters protects mice against systemic Streptococcus pneumoniae infection. Infect. Immun. 2001, 69, 6702-6706. [CrossRef] [PubMed]

24. Ogunniyi, A.D.; Folland, R.L.; Briles, D.E.; Hollingshead, S.K.; Paton, J.C. Immunization of mice with combinations of pneumococcal virulence proteins elicits enhanced protection against challenge with Streptococcus pneumoniae. Infect. Immun. 2000, 68, 3028-3033. [CrossRef]

25. Ogunniyi, A.D.; Woodrow, M.C.; Poolman, J.T.; Paton, J.C. Protection against Streptococcus pneumoniae elicited by immunization with pneumolysin and CbpA. Infect. Immun. 2001, 69, 5997-6003. [CrossRef] [PubMed]

26. Masomian, M.; Ahmad, Z.; Gew, L.T.; Poh, C.L. Development of next generation Streptococcus pneumoniae vaccines conferring broad protection. Vaccines 2020,8, 132. [CrossRef]

27. Corsini, B.; Aguinagalde, L.; Ruiz, S.; Domenech, M.; Antequera, M.L.; Fenoll, A.; García, P.; García, E.; Yuste, J. Immunization with LytB protein of Streptococcus pneumoniae activates complement-mediated phagocytosis and induces protection against pneumonia and sepsis. Vaccine 2016, 34, 6148-6157. [CrossRef] [PubMed]

28. Lock, R.A.; Hansman, D.; Paton, J.C. Comparative efficacy of autolysin and pneumolysin as immunogens protecting mice against infection by Streptococcus pneumoniae. Microb. Pathog. 1992, 12, 137-143. [CrossRef]

29. Canvin, J.R.; Marvin, A.P.; Sivakumaran, M.; Paton, J.C.; Boulnois, G.J.; Andrew, P.W.; Mitchell, T.J. The role of pneumolysin and autolysin in the pathology of pneumonia and septicemia in mice infected with a type 2 pneumococcus. J. Infect. Dis. 1995 172, 119-123. [CrossRef] [PubMed]

30. Ramos-Sevillano, E.; Urzainqui, A.; Campuzano, S.; Moscoso, M.; González-Camacho, F.; Domenech, M.; Rodríguez de Córdoba, S.; Saánchez-Madrid, F.; Brown, J.S.; García, E.; et al. Pleiotropic effects of cell wall amidase LytA on Streptococcus pneumoniae sensitivity to the host immune response. Infect. Immun. 2015, 83, 591-603. [CrossRef]

31. Eldholm, V.; Johnsborg, O.; Haugen, K.; Ohnstad, H.S.; Håvarstein, L.S. Fratricide in Streptococcus pneumoniae: Contributions and role of the cell wall hydrolases CbpD, LytA and LytC. Microbiology 2009, 155, 2223-2234. [CrossRef] [PubMed]

32. Moscoso, M.; García, E.; López, R. Biofilm formation by Streptococcus pneumoniae: Role of choline, extracellular DNA, and capsular polysaccharide in microbial accretion. J. Bacteriol. 2006, 188, 7785-7795. [CrossRef]

33. Gosink, K.K.; Mann, E.R.; Guglielmo, C.; Tuomanen, E.I.; Masure, H.R. Role of novel choline binding proteins in virulence of Streptococcus pneumoniae. Infect. Immun. 2000, 68, 5690-5695. [CrossRef] [PubMed]

34. Ramos-Sevillano, E.; Moscoso, M.; García, P.; García, E.; Yuste, J. Nasopharyngeal colonization and invasive disease are enhanced by the cell wall hydrolases LytB and LytC of Streptococcus pneumoniae. PLoS ONE 2011, 6, e23626. [CrossRef] [PubMed]

35. Hermoso, J.A.; Lagartera, L.; González, A.; Stelter, M.; García, P.; Martínez-Ripoll, M.; García, J.L.; Menéndez, M. Insights into pneumococcal pathogenesis from the crystal structure of the modular teichoic acid phosphorylcholine esterase Pce. Nat. Struct. Mol. Biol. 2005, 12, 533-538. [CrossRef] [PubMed]

36. García, J.L.; García, E.; López, R. Overproduction and rapid purification of the amidase of Streptococcus pneumoniae. Arch. Microbiol. 1987, 149, 52-56. [CrossRef]

37. García, P.; Paz González, M.; García, E.; García, J.L.; López, R. The molecular characterization of the first autolytic lysozyme of Streptococcus pneumoniae reveals evolutionary mobile domains. Mol. Microbiol. 1999, 33, 128-138. [CrossRef]

38. Sánchez-Puelles, J.M.; Sanz, J.M.; García, J.L.; García, E. Cloning and expression of gene fragments encoding the choline-binding domain of pneumococcal murein hydrolases. Gene 1990, 89, 69-75. [CrossRef]

39. Lagartera, L.; González, A.; Stelter, M.; García, P.; Kahn, R.; Menéndez, M.; Hermoso, J.A. Crystallization and preliminary X-ray diffraction studies of the pneumococcal teichoic acid phosphorylcholine esterase Pce. Acta Crystallogr. Sect. F Struct. Biol. Cryst. Commun. 2005, 61, 221-224. [CrossRef] [PubMed]

40. Jomaa, M.; Yuste, J.; Paton, J.C.; Jones, C.; Dougan, G.; Brown, J.S. Antibodies to the iron uptake ABC transporter lipoproteins PiaA and PiuA promote opsonophagocytosis of Streptococcus pneumoniae. Infect. Immun. 2005, 73, 6852-6859. [CrossRef]

41. Cafini, F.; Yuste, J.; Gimenez, M.J.; Sevillano, D.; Aguilar, L.; Alou, L.; Ramos-Sevillano, E.; Torrico, M.; Gonzalez, N.; Garcia, E.; et al. Enhanced in vivo activity of cefditoren in pre-immunized mice against penicillin-resistant S. pneumoniae (serotypes 6B, 19F and 23F) in a sepsis model. PLoS ONE 2010, 5, e12041. [CrossRef] [PubMed] 
42. Yuste, J.; Sen, A.; Truedsson, L.; Jönsson, G.; Tay, L.S.; Hyams, C.; Baxendale, H.E.; Goldblatt, F.; Botto, M.; Brown, J.S. Impaired opsonization with $\mathrm{C} 3 \mathrm{~b}$ and phagocytosis of Streptococcus pneumoniae in sera from subjects with defects in the classical complement pathway. Infect. Immun. 2008, 76, 3761-3770. [CrossRef]

43. Ramos-Sevillano, E.; Rodríguez-Sosa, C.; Cafini, F.; Giménez, M.J.; Navarro, A.; Sevillano, D.; Alou, L.; García, E.; Aguilar, L.; Yuste, J. Cefditoren and ceftriaxone enhance complement-mediated immunity in the presence of specific antibodies against antibiotic-resistant pneumococcal strains. PLoS ONE 2012, 7, e44135. [CrossRef] [PubMed]

44. Ramos-Sevillano, E.; Rodríguez-Sosa, C.; Díez-Martínez, R.; Giménez, M.J.; Olmedillas, E.; García, P.; García, E.; Aguilar, L.; Yuste, J. Macrolides and beta-lactam antibiotics enhance $\mathrm{C} 3 \mathrm{~b}$ deposition on the surface of multidrug-resistant Streptococcus pneumoniae strains by a LytA autolysin-dependent mechanism. Antimicrob. Agents Chemother. 2012, 56, 5534-5540. [CrossRef] [PubMed]

45. Exley, R.M.; Shaw, J.; Mowe, E.; Sun, Y.H.; West, N.P.; Williamson, M.; Botto, M.; Smith, H.; Tang, C.M. Available carbon source influences the resistance of Neisseria meningitidis against complement. J. Exp. Med. 2005, 201, 1637-1645. [CrossRef] [PubMed]

46. Romero-Steiner, S.; Libutti, D.; Pais, L.B.; Dykes, J.; Anderson, P.; Whitin, J.C.; Keyserling, H.L.; Carlone, G.M. Standardization of an opsonophagocytic assay for the measurement of functional antibody activity against Streptococcus pneumoniae using differentiated HL-60 cells. Clin. Diagn. Lab. Immunol. 1997, 4, 415-422. [CrossRef] [PubMed]

47. Ramos-Sevillano, E.; Urzainqui, A.; de Andrés, B.; González-Tajuelo, R.; Domenech, M.; González-Camacho, F.; Sánchez-Madrid, F.; Brown, J.S.; García, E.; Yuste, J. PSGL-1 on leukocytes is a critical component of the host immune response against invasive pneumococcal disease. PLoS Pathog. 2016, 12, e1005500. [CrossRef] [PubMed]

48. López, R.; García, E. Recent trends on the molecular biology of pneumococcal capsules, lytic enzymes, and bacteriophage. FEMS Microbiol. Rev. 2004, 28, 553-580. [CrossRef] [PubMed]

49. Morales, M.; García, P.; de la Campa, A.G.; Linares, J.; Ardanuy, C.; García, E. Evidence of localized prophage-host recombination in the lytA gene, encoding the major pneumococcal autolysin. J. Bacteriol. 2010, 192, 2624-2632. [CrossRef] [PubMed]

50. Sakai, F.; Talekar, S.J.; Lanata, C.F.; Grijalva, C.G.; Klugman, K.P.; Vidal, J.E.; Group, R.P.; Investigators, G. Expression of Streptococcus pneumoniae virulence-related genes in the nasopharynx of healthy children. PLoS ONE 2013, 8, e67147. [CrossRef]

51. Desa, M.N.; Sekaran, S.D.; Vadivelu, J.; Parasakthi, N. Distribution of CBP genes in Streptococcus pneumoniae isolates in relation to vaccine types, penicillin susceptibility and clinical site. Epidemiol. Infect. 2008, 136, 940-942. [CrossRef]

52. Bologa, M.; Kamtchoua, T.; Hopfer, R.; Sheng, X.; Hicks, B.; Bixler, G.; Hou, V.; Pehlic, V.; Yuan, T.; Gurunathan, S. Safety and immunogenicity of pneumococcal protein vaccine candidates: Monovalent choline-binding protein A (PcpA) vaccine and bivalent PcpA-pneumococcal histidine triad protein D vaccine. Vaccine 2012, 30, 7461-7468. [CrossRef]

53. Kamtchoua, T.; Bologa, M.; Hopfer, R.; Neveu, D.; Hu, B.; Sheng, X.; Corde, N.; Pouzet, C.; Zimmermann, G.; Gurunathan, S. Safety and immunogenicity of the pneumococcal pneumolysin derivative PlyD1 in a single-antigen protein vaccine candidate in adults. Vaccine 2013, 31, 327-333. [CrossRef] [PubMed]

54. Uddin, S.; Borrow, R.; Haeney, M.R.; Moran, A.; Warrington, R.; Balmer, P.; Arkwright, P.D. Total and serotype-specific pneumococcal antibody titres in children with normal and abnormal humoral immunity. Vaccine 2006, 24, 5637-5644. [CrossRef] [PubMed]

55. Lottenbach, K.R.; Mink, C.M.; Barenkamp, S.J.; Anderson, E.L.; Homan, S.M.; Powers, D.C. Age-associated differences in immunoglobulin G1 (IgG1) and IgG2 subclass antibodies to pneumococcal polysaccharides following vaccination. Infect. Immun. 1999, 67, 4935-4938. [CrossRef] [PubMed]

56. Shelly, M.A.; Jacoby, H.; Riley, G.J.; Graves, B.T.; Pichichero, M.; Treanor, J.J. Comparison of pneumococcal polysaccharide and CRM197-conjugated pneumococcal oligosaccharide vaccines in young and elderly adults. Infect. Immun. 1997, 65, 242-247. [CrossRef] [PubMed]

57. Wuorimaa, T.; Kayhty, H.; Leroy, O.; Eskola, J. Tolerability and immunogenicity of an 11-valent pneumococcal conjugate vaccine in adults. Vaccine 2001, 19, 1863-1869. [CrossRef]

58. Soininen, A.; Seppala, I.; Nieminen, T.; Eskola, J.; Kayhty, H. IgG subclass distribution of antibodies after vaccination of adults with pneumococcal conjugate vaccines. Vaccine 1999, 17, 1889-1897. [CrossRef]

59. Amir, J.; Scott, M.G.; Nahm, M.H.; Granoff, D.M. Bactericidal and opsonic activity of IgG1 and IgG2 anticapsular antibodies to Haemophilus influenzae type b. J. Infect. Dis. 1990, 162, 163-171. [CrossRef] [PubMed]

60. Bredius, R.G.; Driedijk, P.C.; Schouten, M.F.; Weening, R.S.; Out, T.A. Complement activation by polyclonal immunoglobulin G1 and G2 antibodies against Staphylococcus aureus, Haemophilus influenzae type b, and tetanus toxoid. Infect. Immun. 1992, 60, 4838-4847. [CrossRef]

61. Brown, J.S.; Hussell, T.; Gilliland, S.M.; Holden, D.W.; Paton, J.C.; Ehrenstein, M.R.; Walport, M.J.; Botto, M. The classical pathway is the dominant complement pathway required for innate immunity to Streptococcus pneumoniae infection in mice. Proc. Natl. Acad. Sci. USA 2002, 99, 16969-16974. [CrossRef] [PubMed]

62. Ahn, J.G.; Kim, H.W.; Choi, H.J.; Lee, J.H.; Kim, K.H. Functional immune responses to twelve serotypes after immunization with a 23-valent pneumococcal polysaccharide vaccine in older adults. Vaccine 2015, 33, 4770-4775. [CrossRef] [PubMed]

63. Kaur, R.; Pichichero, M. Comparison of anti-capsular antibody quantity and functionality in children after different primary dose and booster schedules of 13 valent-pneumococcal conjugate vaccine. Vaccine 2020, 38, 4423-4431. [CrossRef] [PubMed]

64. Standish, A.J.; Weiser, J.N. Human neutrophils kill Streptococcus pneumoniae via serine proteases. J. Immunol. 2009, 183, 2602-2609. [CrossRef] [PubMed] 
65. Johansson, P.J.; Sternby, E.; Ursing, B. Septicemia in granulocytopenic patients: A shift in bacterial etiology. Scand. J. Infect. Dis. 1992, 24, 357-360. [CrossRef]

66. Briles, D.E.; Claflin, J.L.; Schroer, K.; Forman, C. Mouse Igg3 antibodies are highly protective against infection with Streptococcus pneumoniae. Nature 1981, 294, 88-90. [CrossRef]

67. Wizemann, T.M.; Heinrichs, J.H.; Adamou, J.E.; Erwin, A.L.; Kunsch, C.; Choi, G.H.; Barash, S.C.; Rosen, C.A.; Masure, H.R.; Tuomanen, E.; et al. Use of a whole genome approach to identify vaccine molecules affording protection against Streptococcus pneumoniae infection. Infect. Immun. 2001, 69, 1593-1598. [CrossRef] [PubMed]

68. Yuan, Z.Q.; Lv, Z.Y.; Gan, H.Q.; Xian, M.; Zhang, K.X.; Mai, J.Y.; Yu, X.B.; Wu, Z.D. Intranasal immunization with autolysin (LytA) in mice model induced protection against five prevalent Streptococcus pneumoniae serotypes in China. Immunol. Res. 2011, 51, 108-115. [CrossRef]

69. Lipsitch, M.; Siber, G.R. How Can Vaccines Contribute to Solving the Antimicrobial Resistance Problem? mBio 2016, 7. [CrossRef] [PubMed]

70. Rosini, R.; Nicchi, S.; Pizza, M.; Rappuoli, R. Vaccines Against Antimicrobial Resistance. Front. Immunol. 2020, 11, 1048. [CrossRef] [PubMed]

71. Domenech, M.; Sempere, J.; de Miguel, S.; Yuste, J. Combination of antibodies and antibiotics as a promising strategy against multidrug-resistant pathogens of the respiratory tract. Front. Immunol. 2018, 9. [CrossRef] [PubMed]

72. Azoulay-Dupuis, E.; Rieux, V.; Muffat-Joly, M.; Bedos, J.P.; Vallee, E.; Rivier, C.; Isturiz, R.; Carbon, C.; Moine, P. Relationship between capsular type, penicillin susceptibility, and virulence of human Streptococcus pneumoniae isolates in mice. Antimicrob. Agents Chemother. 2000, 44, 1575-1577. [CrossRef] [PubMed]

73. Rieux, V.; Carbon, C.; Azoulay-Dupuis, E. Complex relationship between acquisition of beta-lactam resistance and loss of virulence in Streptococcus pneumoniae. J. Infect. Dis. 2001, 184, 66-72. [CrossRef] [PubMed]

74. Read, R.C.; Dull, P.; Bai, X.; Nolan, K.; Findlow, J.; Bazaz, R.; Kleinschmidt, A.; McCarthy, M.; Wang, H.; Toneatto, D.; et al. A phase III observer-blind randomized, controlled study to evaluate the immune response and the correlation with nasopharyngeal carriage after immunization of university students with a quadrivalent meningococcal ACWY glycoconjugate or serogroup B meningococcal vaccine. Vaccine 2017, 35, 427-434. [CrossRef] [PubMed]

75. Marshall, H.S.; McMillan, M.; Koehler, A.P.; Lawrence, A.; Sullivan, T.R.; MacLennan, J.M.; Maiden, M.C.J.; Ladhani, S.N.; Ramsay, M.E.; Trotter, C.; et al. Meningococcal B Vaccine and Meningococcal Carriage in Adolescents in Australia. N. Engl. J. Med. 2020, 382, 318-327. [CrossRef] 